\title{
PENINGKATAN HASIL BELAJAR MATEMATIKA MATERI VEKTOR MELALUI MODEL PEMBELAJARAN KOOPERATIF TIPE STUDENT TEAM ACHIEVEMENT DIVISION (STAD)
}

\author{
SITI RAHMATUN HAYATI \\ MAN 4 Sleman \\ e-mail: rahma.math2@gmail.com
}

\begin{abstract}
ABSTRAK
Pembelajaran matematika yang cenderung monoton akan menyebabkan rasa bosan dan bagi peserta didik. Hal ini bisa dilihat dari antusiasme mereka mengikuti pembelajaran. Mereka perhatian ketika guru memberikan materi dan contoh soal, tetapi ketika mengerjakan soal, mereka mengalami kesulitan. Oleh karena itu, maka perlu dipikirkan cara penyajian dan suasana pembelajaran matematika yang cocok buat peserta didik, sehingga peserta didik dapat berpartisipasi aktif dalam proses pembelajaran. Model yang cocok adalah model kooperatif. Salah satu model kooperatif adalah tipe STAD. Pada tipe ini guru memberikan suatu materi, yang selanjutnya dalam kelompok peserta didik akan diperdalam lebih lanjut. Pada saat guru presentasi, peserta didik harus benar-benar memperhatikan, sehingga nantinya ketika mengerjakan kuis tidak mengalami kesulitan.Dalam kelompoknya, semua peserta didik dipastikan dapat menguasai materi yang dipelajari.Penelitian tindakan kelas ini dilakukan untuk mengetahui peningkatkan hasil belajar Matematika pada materi vektor pada peserta didik kelas X MIPA 1 semester genap Tahun Ajaran 2019/2020 setelah mengikuti proses pembelajaran dengan menerapkan model pembelajaran kooperatif tipe STAD. Metode pengumpulan data menggunakan metode observasi dan tes. Teknik yang digunakan dalam penelitian ini adalah teknik deskriptik analitik yaitu data kuantitatif yang diperoleh dari hasil kuis yang diolah dengan menggunakan deskripsi persentase dan data kualitatif yang diperoleh dari observasi tentang kegiatan guru dan peserta didik dijadikan dasar untuk mendeskripsikan keberhasilan penerapan model pembelajaran kooperatif tipe STAD. Hasil belajar peserta didik dari siklus I dan siklus II mengalami peningkatan. Untuk siklus I nilai rata-ratanya 54,17. Sedangkan pada siklus II nilai rata-ratanya 67,92. Persentase ketuntasan hasil belajar peserta didik pada siklus I sebesar 37,50\% dan pada siklus II sebesar 79,20\%. Dengan demikian hipotesis penelitian ini terbukti. Tindakan dikatakan berhasil jika ada peningkatan hasil belajar dari siklus I ke siklus II dan persentase peserta didik yang mencapai nilai KKM (tuntas) sudah mencapai minimal $75 \%$. Maka PTK ini dinyatakan telah berhasil meningkatkan hasil belajar peserta didik.
\end{abstract}

Kata kunci : model kooperatif, STAD, hasil belajar

\section{ABSTRACT}

Learning mathematics that tends to be monotonous will cause boredom and for students. This can be seen from their enthusiasm for learning. They pay attention when the teacher provides material and sample questions, but when working on the questions, they have difficulty. Therefore, it is necessary to think about ways of presenting and learning mathematics that are suitable for students, so that students can actively participate in the learning process. The suitable model is the cooperative model. One of the cooperative models is the STAD type. In this type, the teacher provides material, which in the next group of students will be deepened further. At the time of the teacher's presentation, students must really pay attention, so that later when doing quizzes they will not experience difficulties. In the group, all students can certainly master the material being studied. students of class X MIPA 1 in the even semester of the 2019/2020 Academic Year after participating in the learning process by applying the STAD type cooperative learning model. Methods of collecting data using the method of observation and tests. The technique used in this research is descriptive analytical technique, namely quantitative data obtained from quiz results that are processed using percentage descriptions and qualitative data obtained from observations about teacher and student activities are used as 
the basis for describing the successful application of the STAD type cooperative learning model. Student learning outcomes from cycle I and cycle II have increased. For the first cycle the average value is 54.17. While in the second cycle the average value is 67.92. The percentage of complete learning outcomes of students in the first cycle is $37.50 \%$ and in the second cycle is $79.20 \%$. Thus the research hypothesis is proven. The action is said to be successful if there is an increase in learning outcomes from cycle I to cycle II and the percentage of students who achieve the KKM (completed) score has reached a minimum of $75 \%$. So this CAR is declared to have succeeded in improving student learning outcomes.

Keywords: cooperative model, STAD, learning outcomes

\section{PENDAHULUAN}

Pembelajaran yang sebagian besar dilakukan guru matematika selama ini adalah pembelajaran dengan urutan menjelaskan obyek matematika, memberi contoh matematika yang baru dijelaskannya, meminta peserta didik untuk menyelesaikan soal yang serupa dengan contoh, dan memberi latihan soal. Latihan soal yang diberikan biasanya cukup bervariasi, diawali dari soal yang mirip dengan contoh sampai dengan aplikasi obyek matematika dalam kehidupan sehari-hari.

Pembelajaran matematika seperti itu cenderung membuat peserta didik merasa bosan dan kurang tertarik. Hal ini nampak dari peserta didik ketika berpartisipasi dalam pembelajaran. Mereka berpartisipasi hanya saat mengerjakan soal latihan. Selama proses perolehan konsep, peserta didik lebih banyak menyimak dan mendengarkan informasi dari guru. Ketika guru membahas hasil pekerjaan temannya, mereka memperhatikan dengan seksama. Nampaknya semua peserta didik sangat memahami langkah-langkah menyelesaikan masalah yang ditugaskan gurunya. Tetapi ketika guru memberi latihan yang lain, mereka nampak mengalami kesulitan. Mereka seolah-olah merasa asing dengan soal latihan yang diberikan gurunya. Hanya beberapa orang peserta didik saja yang langsung dapat menyelesaikannya. Situasi seperti itu selalu terulang dari topik yang satu ke topik yang lain. Untuk mengantisipasinya, guru biasanya memberikan pekerjaan rumah sebagai latihan tambahan. Guru berharap peserta didik lebih banyak melatih dirinya di rumah, agar tidak tertinggal oleh temannya yang lain. Tidak jarang tugas diberikan secara berkelompok.

Oleh karena itu, maka perlu dipikirkan cara penyajian dan suasana pembelajaran matematika yang cocok buat peserta didik, sehingga peserta didik dapat berpartisipasi aktif dalam proses pembelajaran. Saat ini banyak model-model pembelajaran yang banyak dikembangkan. Salah satu model pembelajaran yang disosialisasikan adalah model pembelajaran kooperatif. Model pembelajaran kooperatif ini memiliki beberapa tipe, antara lain Student Teams Achievement Division (STAD), Jigsaw, Investigasi Kelompok, dan lain-lain.

Pembelajaran Kooperatif mencakup suatu kelompok kecil peserta didik yang bekerja sebagai sebuah tim untuk menyelesaikan sebuah masalah, menyelesaikan suatu tugas, atau untuk mengerjakan sesuatu untuk mencapai tujuan bersama lainnya. Bukanlah pembelajaran kooperatif jika peserta didik duduk bersama dalam kelompok-kelompok kecil dan mempersilahkan salah seorang diantaranya untuk menyelesaikan pekerjaan seluruh kelompok. Kelompok dibentuk dari peserta didik yang memiliki kemampuan tinggi, sedang, dan rendah.

Pembelajaran kooperatif tidak sama dengan sekedar belajar dalam kelompok. Ada unsur dasar pembelajaran kooperatif yang membedakan dengan pembelajaran kelompok yang dilakukan asal-asalan. Dalam pembelajaran kooperatif, proses pembelajaran tidak harus belajar dari guru kepada peserta didik, peserta didik dapat saling membelajarkan sesama peserta didik lainnya.

Ciri-ciri pembelajaran kooperatif (Rusman, 2010:208-209) adalah peserta didik bekerja dalam kelompok secara kooperatif untuk menuntaskan materi belajarnya, bilamana mungkin, anggota kelompok berasal dari ras, budaya, suku, jenis kelamin berbeda-beda dan penghargaan lebih berorientasi kelompok ketimbang individu. 
Model kooperatif tipe STAD (Student Team Achievement Division) dikembangkan oleh Robert Slavin dan teman-temannya di Universitas John Hopkin (dalam Slavin, 2010), dan merupakan pendekatan pembelajaran kooperatif paling sederhana dan yang paling banyak diteliti.Dalam STAD, peserta didik dibagi menjadi kelompok-kelompok yang beranggotakan 4-5 orang dengan memperhatikan kemampuan, jenis kelamin, suku bangsa dan beragam perbedaaan lain. Guru memberikan suatu materi, yang selanjutnya dalam kelompok peserta didik akan diperdalam lebih lanjut. Pada saat guru presentasi, peserta didik harus benar-benar memperhatikan, sehingga nantinya ketika mengerjakan kuis tidak mengalami kesulitan.Dalam kelompoknya, semua peserta didik dipastikan dapat menguasai materi yang dipelajari.

Selanjutnya, akan diadakan kuis atau tes yang bersifat individu. Para peserta didik tidak diperbolehkan saling membantu dalam mengerjakan kuis. Sehingga, tiap peserta didik bertanggung jawab secara individual untuk memahami materinya. Nilai-nilai kuis, akan dibandingkan dengan nilai mereka sendiri yang diperoleh sebelumnya, dan nilai-nilai itu diberi hadiah berdasarkan seberapa tinggi peningkatan yang bisa mereka capai. Nilai masing-masing individu dijumlahkan sebagai nilai kelompok, dan kelompok yang mencapai criteria tertentu bisa mendapatkan hadiah.Lebih lanjut Slavin (Rusman,2010:216) memaparkan bahwa "Gagasan utama di belakang STAD adalah memacu peserta didik agar saling mendorong dan membantu satu sama lain untuk menguasai keterampilan yang diajarkan guru". Jika kelompoknya ingin mendapatkan hadiah, maka sesama anggota kelompok harus saling membantu untuk bisa memahami materi pelajaran yang diberikan. Para peserta didik diberi waktu untuk bekerja sama setelah pelajaran diberikan oleh guru, tetapi tidak saling membantu ketika menjalani tes, sehingga setiap peserta didik harus menguasai materi tersebut (tanggung jawab perseorangan).

Hasil belajar matematika pada peserta didik MAN 4 Sleman selama ini belum memuaskan. Berdasarkan rata-rata hasil PTS dan PAS peserta didik MAN 4 Sleman pada mata pelajaran matematika peminatan di kelas X MIPA semester gasal tahun pelajaran 2019/2020 masih sangat rendah. Rata-rata nilai PTS hanya 29,81 dan dengan nilai KKM 70, hanya satu orang yang nilainya melebihi KKM, sedangkan rata-rata PAS 25,61 dan tidak ada peserta didik yang mencapai ketuntasan. Hal ini tentu saja sangat jauh dari harapan yang diinginkan.

Oleh karena itu, maka perlu dipikirkan cara penyajian dan suasana pembelajaran matematika yang cocok buat peserta didik, sehingga peserta didik dapat berpartisipasi aktif dalam proses pembelajaran. Dengan tipe STAD, diharapkan semua peserta didik dapat berpartisipasi aktif dalam pembelajaran, karena semua peserta didik dalam satu kelompok akan saling membantu untuk memahami materi yang dipelajari. Disamping itu, akan terjadi kompetisi yang sehat untuk masing-masing kelompok. Model pembelajaran kooperatif ini memungkinkan peserta didik untuk berpartisipasi aktif dalam pembelajaran. Semakin tinggi partisipasi aktif peserta didik, diharapkan hasil belajar yang diperoleh peserta didik juga akan meningkat.

Hasil belajar memiliki kedudukan yang sangat penting dan tidak dapat dipisahkan dari proses pembelajaran. Hasil belajar merupakan tolak ukur keberhasilan suatu proses pembelajaran. Dengan hasil belajar, guru dapat mengetahui apakah siswa sudah mencapai kompetensi yang sudah ditetapkan. Hasil belajar siswa adalah salah satu indikator keberhasilan pendidikan yang berlangsung disekolah dan diperoleh melalui suatu proses pembelajaran sekalikus untuk menyatakan tingkat keberhasilan yang dicapai seseorang siswa setelah melalui aktifitas belajar. Hasil belajar yang telah dicapai dapat diukur melalui tes kemajuan yang diperoleh siswa setelah dia belajar dengan memberikan nilai dari berbagai aspek.

\section{METODE PENELITIAN}

Penelitian Tindakan Kelas ini dilaksanakan di kelas X MIPA 1 MAN 4 Sleman. Jumlah keseluruhan peserta didik di kelas X MIPA 1 adalah 24 peserta didik. Rinciannya, peserta didik perempuan ada 15 anak, peserta didik laki-laki ada 9 anak, yang berasal dari SMP sebanyak 16 
peserta didik dan yang berasal dari MTs sebanyak 8 peserta didik. Penelitian ini adalah Penelitian Tindakan Kelas (PTK). PTK dilaksanakan dalam bentuk proses pengkajian berdaur 4 tahap, yaitu (1) merencanakan, (2) melakukan tindakan, (3) mengamati (observasi), dan (4) merefleksi. Secara skema :

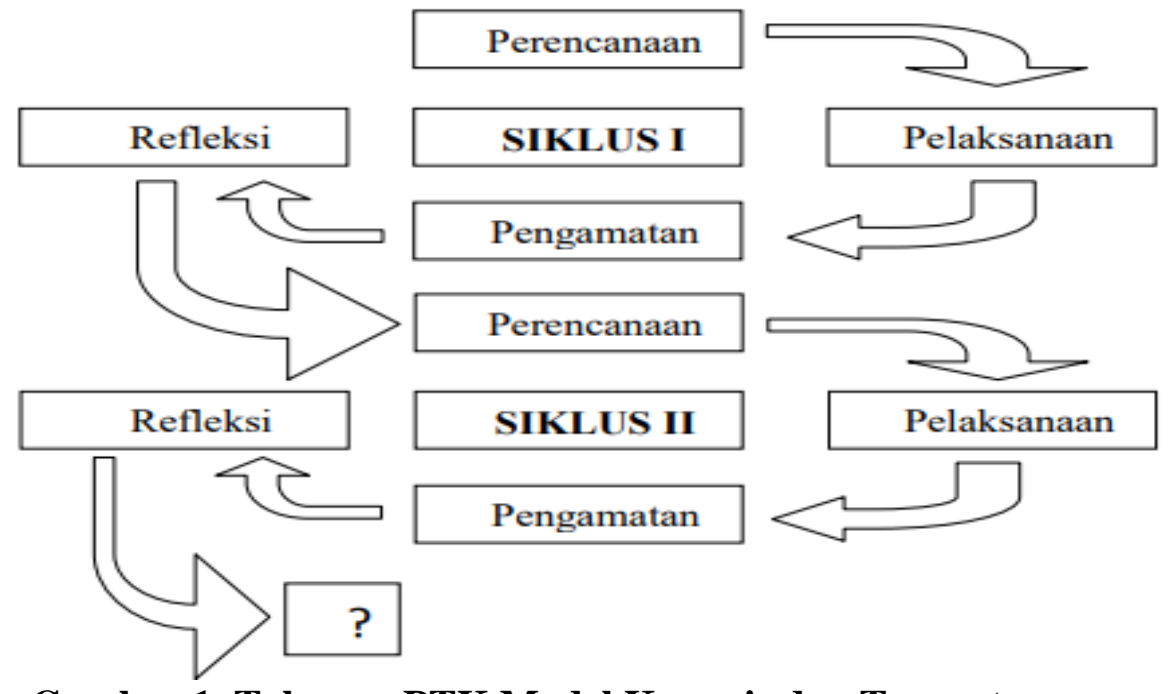

Gambar 1. Tahapan PTK Model Kemmis dan Taggart

(Arikunto. 2010)

Pada tahap perencanaan guru merencanakan pembelajaran dengan menyusun RPP pada materi vektor di ruang dimensi dua, menyiapkan bahan ajar, sumber dan bahan presentasi, Lembar Kerja Peserta Didik, lembar observasi aktivitas guru dan peserta didik dalam proses belajar mengajar.Selanjutnya, dilaksanakan kegiatan belajar mengajar yang diamati oleh observer kemudian diadakan refleksi di akhir siklus.Penelitian ini akan dilakukan dalam dua siklus. Setiap siklus dilakukan dua kali pertemuan dan diakhiri dengan tes untuk masing-masig siklus. Hasil yang diharapkan setiap siklus adalah hasil belajar yang meningkat.

Penelitian Tindakan Kelas ini dilaksanakan untuk meneliti tentang peningkatan hasil belajar peserta didik kelas X MIPA 1 dalam proses pembelajaran menggunakan model pembelajaran kooperatif tipe STAD. Saat pembelajaran sedang berlangsung dengan melibatkan observer yang bertugas mengamati aktivitas guru selama melaksanakan proses pembelajaran serta mengamati aktivitas peserta didik saat mengikuti pembelajaran dengan menggunakan model pembelajaran kooperatif tipe STAD. Penelitian tindakan kelas ini menggunakan metode observasi dan tes. Metode observasi digunakan untuk memperoleh data tentang proses pelaksanaan tindakan (PBM) yang menggunakan model pembelajaran tipe STAD. Pelaksanaan observasi ini, peneliti dibantu oleh observer (teman sejawat) dengan maksud agar proses pembelajaran dilakukan sedetail mungkin dari aspek langkah-langkah pembelajaran, perilaku guru dan peserta didik. Untuk melakukan observasi, peneliti menggunakan lembar observasi kegiatan guru maupun peserta didik.

Sedangkan metode tes digunakan untuk memperoleh data hasil belajar peserta didik. Tes yang digunakan adalah tes tertulis berupa soal-soal pilihan ganda. Tes diberikan setelah selesai 2 kali pertemuan (untuk setiap siklus). Teknik yang digunakan untuk analisi data pada penelitian ini adalah teknik deskriptik analitik yaitu data kuantitatif diperoleh dari hasil kuis yang diolah dengan menggunakan deskripsi persentase. Nilai yang diperoleh peserta didik dikategorikan sebagai belum tuntas dan tuntas dengan nilai KKM 70. Dari rekapitulasi nilai pada setiap siklus dilakukan persentase nilai siswa yang belum tuntas dan persentase nilai peserta didik yang sudah tuntas. Dengan melihat persentase siklus I dan siklus II dapat diketahui apakah hasil belajarnya meningkat. Hasil belajar dikatakan meningkat jika ada peningkatan nilai rata-rata kelas dan persentase nilai peserta didik yang tuntas. Sedangkan data kualitatif yang diperoleh dari observasi tentang kegiatan guru dan peserta didik dijadikan dasar untuk 
mendeskripsikan keberhasilan penerapan model pembelajaran kooperatif tipe STAD. Selain itu juga sebagai dasar saat melakukan refleksi dan perbaikan pembelajaran setiap siklus.

\section{HASIL DAN PEMBAHASAN}

Hasil

Penelitian yang telah dilakukan oleh penulis sebagai peneliti sejak mulai siklus I hingga siklus II pada bulan Januari hingga Februari 2020 dibantu oleh seorang guru Matematika bernama Inta Prihandini, S.Pd sebagai observer dan berfungsi sebagai teman sejawat dalam berdiskusi pada tahap refleksi.

\section{SIKLUS 1}

Proses pembelajaran siklus I direncanakan sebanyak dua kali pertemuan yakni Selasa, 28 Januari 2020 ( 2 x 45 menit) dan Selasa, 4 Februari 2020 ( 2 x 45 menit). Penelitian ini dilaksanakan pada kelas X MIPA 1 dengan jumlah 24 peserta didik.

Adapun hasil observasi pelaksanaan yang ditemukan pada siklus 1 bahwa pelaksanaan proses pembelajaran yang dilakukan oleh peneliti pada pelaksanaan siklus I pertemuan 1 ada beberapa langkah yang yang harus ditingkatkan skornya yakni memberi kesempatan bertanya kepada peserta didik, menunjuk perwakilan kelompok untuk menyampaikan hasil diskusinya dan membimbing peserta didik menyimpulkan materi yang telah dipelajari.

Pertemuan kedua, guru mendapat masukan dari observer agar memperbaiki langkahlangkah yang dilaksanakan kurang sempurna atau yang sudah dilaksanakan cukup sempurna. Berdasarkan masukan dan arahan dari observer guru selanjutnya merubah dan memperbaiki langkah-langkah dalam melaksanakan pembelajaran.

Setelah diadakan perhitungan rata-rata skor pada pertemuan 1 dan pertemuan 2 diperoleh hasil capaian kinerja guru dalam melaksanakan pembelajaran adalah 46, sehingga apabila merujuk pada Permeneg PAN dan RAB No. 16 Tahun 2009 dalam Buku 2 PKG tentang capaian kinerja guru dalam mengajar adalah 76,67. Angka ini menunjukan kualifikasi kinerja guru adalah Baik.

\section{Observasi Hasil Belajar Peserta didik Peserta Didik}

Pada akhir siklus I diadakan kuis untuk mengetahui hasil belajar peserta didik. Adapun hasilnya sebagai berikut :

Tabel 1 Hasil Belajar Individu Siklus I

\begin{tabular}{|c|c|c|c|}
\hline No & Nilai & Frekuensi & keterangan \\
\hline 1 & 20 & 2 & Belum tuntas \\
\hline 2 & 30 & 2 & Belum tuntas \\
\hline 3 & 40 & 3 & Belum tuntas \\
\hline 4 & 50 & 6 & Belum tuntas \\
\hline 5 & 60 & 2 & Belum tuntas \\
\hline 6 & 70 & 6 & Tuntas \\
\hline 7 & 80 & 3 & Tuntas \\
\hline \multicolumn{2}{|l|}{ Rata-Rata } & 54,17 & \\
\hline \multicolumn{2}{|l|}{ Pumlah Yang Tuntas } & 9 & \\
\hline
\end{tabular}

Hasil evaluasi yang dilakukan di siklus I terlihat seperti data pada tabel di atas. Nilai peserta didik di siklus I setelah dilakukan model pembelajaran kooperatif tipe STAD (Student Teams Achievement Divisions), diketahui bahwa nilai rata-rata yang diperoleh peserta didik secara keseluruhan yaitu 54,17. 
Untuk hasil belajar kelompok, disajikan dalam tabel berikut :

Tabel 2 Hasil Belajar Kelompok Siklus I

\begin{tabular}{|c|c|c|c|}
\hline \multirow{2}{*}{ KELOMPOK } & \multicolumn{3}{|c|}{ NILAI } \\
\cline { 2 - 4 } & P 1 & P 2 & $\begin{array}{c}\text { RATA- } \\
\text { RATA }\end{array}$ \\
\hline 1 & 78 & 98 & 88 \\
\hline 2 & 74 & 93 & 83.5 \\
\hline 3 & 80 & 73 & 76.5 \\
\hline 4 & 70 & 98 & 84 \\
\hline 5 & 73 & 89 & 81 \\
\hline 6 & 60 & 62 & 61 \\
\hline Rata-rata & & 79 \\
\hline Nilai Tertinggi & & 88 \\
\hline Nilai Terendah & & 61 \\
\hline
\end{tabular}

Keterangan : P 1 = Pertemuan 1, P $2=$ Pertemuan 2

Tabel diatas dapat menunjukan bahwa jumlah peserta didik sebanyak 24, dibagi menjadi 6 kelompok, masing-masing kelompok berjumlah 4 peserta didik. Dari 6 kelompok tersebut, pada pertemuan pertama, 5 kelompok berhasil mendapatkan hasil belajar mencapai batas KKM dan ada satu kelompok yaitu kelompok 6 yang mendapat hasil belajar belum mencapai batas KKM. Pada pertemuan ke dua kelompok 6 juga belum berhasil mendapatkan nilai mencapai batas KKM.

Nilai rata-rata untuk siklus I ini adalah 79. Nilai tertinggi untuk pertemuan pertama diperoleh kelompok 1 dengan rata-rata nilai 88 dan nilai terendah diperoleh kelompok 6 dengan nilai rata-rata 61.

\section{Refleksi dan Evaluasi Siklus I}

Standar Indikator keberhasilan PTK ini untuk aspek proses pembelajaran adalah adanya peningkatan capaian kualitas kinerja guru dari siklus I ke siklus II. Dari analisis terhadap proses pembelajaran pada siklus I diperoleh capaian kinerja guru sebesar 76,67 dengan kualifikasi Baik.

Standar indikator keberhasilan PTK selanjutnya adalah terjadi peningkatan nilai ratarata hasil belajar dan banyaknya peserta didik yang tuntas mencapai $75 \%$. Dari hasil analisis terhadap hasil belajar peserta didik didapatkan bahwa banyaknya peserta didik yang tuntas baru $37,50 \%$. Oleh karena itu, harus dilakukan tindakan perbaikan pada siklus II.

Berdasarkan pengamatan dari observer bahwa secara umum pembelajaran sudah berlangsung dengan baik, namun ada beberapa yang harus diperbaiki yaitu (1)guru (peneliti) harus mempunyai strategi untuk memancing peserta didik bertanya tentang materi yang belum jelas / paham, (2) guru (peneliti) harus memantau dengan sungguh-sungguh perjalanan diskusi masing-masing kelompok sehingga semua peserta didik dapat menjalankannya dengan serius, (3) uru (peneliti) harus jeli dan teliti dalam mengorganisasi waktu, (4) Guru (peneliti) harus tegas membuat aturan dalam pelaksanaan kuis individu, (5) guru (peneliti) secara umum harus mengoptimalkan langkah-langkah tindakan yang mendapat skor cukup sempurna meningkat ke skor sempurna dilaksanakan .

\section{Siklus II}

Proses pembelajaran siklus II direncanakan sebanyak dua kali pertemuan yakni Sabtu, 15 Februari 2020 ( 1 x 45 menit) dan Selasa, 18 Februari 2020 ( 2 x 45 menit). Pelaksanaan proses pembelajaran yang dilakukan oleh peneliti pada pelaksanaan siklus II pertemuan 1 ada beberapa langkah yang mempunyai skor 2 yaitu memberikan motivasi kepada peserta didik, menyampaikan materi menggunakan media pembelajaran, memberi kesempatan bertanya 
kepada peserta didik, memantau jalannya diskusi kelompok dan membimbing kelompok yang mengalami kesulitan, menunjuk perwakilan kelompok untuk menyampaikan hasil diskusinya, membimbing peserta didik menyimpulkan materi yang telah dipelajari, bersama peserta didik melakukan refleksi tentang pembelajaran yang sudah dilakukan, memberikan tindak lanjut dalam bentuk penugasan individu atau kelompok dan memberikan informasi tentang rencana kegiatan pembelajaran untuk pertemuan berikutnya.

Pertemuan kedua, guru mendapat masukan dari observer agar memperbaiki langkah langkah yang dilaksanakan cukup sempurnaBerdasarkan masukan dan arahan dari observer guru selanjutnya merubah dan memperbaiki langkah-langkah dalam melaksanakan pembelajaran sehingga pada pertemuan ke dua. Setelah dilakukan perhitungan rata-rata skor pertemuan satu dan dua diperoleh jumlah skor capaian kinerja guru 55.5, sehingga apabila merujuk pada Permeneg PAN dan RAB No. 16 Tahun 2009 dalam Buku 2 PKG tentang capaian kinerja guru dalam mengajar adalah 92,5. Angka ini menunjukan kualifikasi kinerja guru adalah Amat Baik.

Pada akhir siklus II diadakan kuis untuk mengetahui hasil belajar peserta didik. Adapun hasilnya sebagai berikut :

Tabel 3. Hasil Belajar Individu Siklus II

\begin{tabular}{|c|c|c|c|}
\hline No & Nilai & Frekuensi & keterangan \\
\hline 1 & 20 & 1 & Belum tuntas \\
\hline 2 & 30 & 2 & Belum tuntas \\
\hline 3 & 40 & 1 & Belum tuntas \\
\hline 4 & 50 & 1 & Belum tuntas \\
\hline 5 & 60 & 0 & Belum tuntas \\
\hline 6 & 70 & 11 & Tuntas \\
\hline 7 & 80 & 4 & Tuntas \\
\hline 8 & 90 & 3 & \\
\hline 9 & 100 & 1 & \\
\hline \multicolumn{2}{|l|}{ Rata-Rata } & 67,92 & 19 \\
\hline \multicolumn{2}{|l}{ Persentase Yang Tuntas } & 79,20 & \\
\hline
\end{tabular}

Hasil evaluasi yang dilakukan di siklus II pada tiap pertemuan terlihat seperti data pada tabel di atas. Nilai rata-rata peserta didik setelah dilakukan model pembelajaran kooperatif tipe STAD (Student Teams Achievement Divisions) yaitu 67,92. Pada kegiatan pembelajaran siklus II ini diperoleh data peserta didik yang sudah tuntas sebanyak 19 peserta didik dari 24 peserta didik atau 79,20\%.

Adapun hasil nilai belajar kelompok sebagai berikut :

Tabel 4 Hasil Belajar Kelompok Siklus I

\begin{tabular}{|c|c|c|c|}
\hline \multirow{2}{*}{ KELOMPOK } & \multicolumn{3}{|c|}{ NILAI } \\
\cline { 2 - 4 } & P 1 & P 2 & RATA-RATA \\
\hline 1 & 90 & 91 & 90.5 \\
\hline 2 & 90 & 95 & 92.5 \\
\hline 3 & 91 & 93 & 92 \\
\hline 4 & 80 & 86 & 83 \\
\hline 5 & 83 & 88 & 85.5 \\
\hline 6 & 80 & 85 & 82.5 \\
\hline \multicolumn{3}{|l}{} & 87.67 \\
\hline Rata-rata & & 92.5 \\
\hline Nilai Tertinggi & & 82.5 \\
\hline
\end{tabular}


Keterangan : P $1=$ Pertemuan 1, P $2=$ Pertemuan 2

Tabel diatas dari 6 kelompok, pada pertemuan pertama dan kedua, semua kelompok sudah berhasil mendapatkan hasil belajar mencapai batas KKM. Nilai rata-rata total untuk pertemuan pertama dan pertemuan kedua adalah 87,67. Rata-rata nilai tertinggi sebesar 92,5 diperoleh kelompok 2, sedangkan untuk rata-rata nilai sebesar 82,5 diperoleh kelompok 6

\section{Refleksi dan Evaluasi Siklus II}

Standar Indikator keberhasilan PTK ini untuk aspek proses pembelajaran adalah adanya peningkatan capaian kualitas kinerja guru dari siklus I ke siklus II. Dari analisis terhadap proses pembelajaran pada siklus I diperoleh capaian kinerja guru sebesar 76,67 dengan kualifikasi kualifikasi Baik. Sedangkan pada siklus II diperoleh capaian kinerja guru sebesar 92,50 dengan kualifikasi Amat Baik. Dengan melihat hasil tersebut kegiatan Penelitian Tindakan Kelas ini telah mencapai indikator keberhasilan.

Standar indikator keberhasilan PTK selanjutnya adalah terjadi peningkatan nilai rata-rata hasil belajar dan banyaknya peserta didik yang tuntas mencapai minimal $75 \%$. Pada siklus I, rata-rata nilai kuis yang diperoleh 54,17 , sedangkan pada siklus II nilai rata-ratanya 67,92. Dengan melihat hasil tersebut, terjadi peninkatan nilai rata-rata dari siklus I ke siklus II atau indikator keberhasilan PTK tercapai. Dari hasil analisis terhadap hasil belajar peserta didik pada kegiatan pembelajaran siklus II diperoleh data peserta didik yang sudah tuntas sebanyak 19 peserta didik dari 24 peserta didik atau 79,20\%. Dengan melihat hasil tersebut kegiatan siklus II sudah mencapai indikator keberhasilan, sehingga tidak perlu diadakan siklus yang ketiga.

Berdasarkan pengamatan dari observer bahwa secara umum pembelajaran sudah berlangsung dengan baik. Namun, ada beberapa yang masih bisa diperbaiki yaitu optimalisasi beberapa aspek yang belum dilakukan dengan sempurna.

Berdasarkan hasil diskusi dengan observer, diperoleh perbaikan sebagai berikut :

1. guru (peneliti) harus membuat media pembelajaran yang lebih efektif dan menarik.

2. guru (peneliti) harus memantau dengan sungguh-sungguh perjalanan diskusi masingmasing kelompok sehingga semua peserta didik dapat menjalankannya dengan serius.

3. Guru (peneliti) secara umum harus mengoptimalkan langkah-langkah tindakan yang medapat skor cukup sempurna (2) meningkat ke skor sempurna dilaksanakan (3)

\section{Pembahasan}

Penerapan model pembelajaran kooperatif tipe STAD (Student Teams Achievement Divisions) menjadikan peserta didik lebih mudah memahami materi pelajaran. Kegiatan pembelajaran dengan model ini memberikan suatu alternatif dalam kegiatan belajar mengajar. Sebelumnya, proses belajar mengajar disekolah ini didominasi oleh guru (teacher centre), peserta didik mendengarkan dan mencatat materi yang diberikan oleh guru. Berbeda dengan setelah diterapkan model pembelajaran kooperatif tipe STAD (Student Teams Achievement Divisions) proses pembelajaran didominasi oleh peserta didik (student centre), peserta didik saling berdiskusi, bertanya dan saling mengutarakan pendapat.

\section{Proses Pembelajaran}

Berdasar pelaksanaan penelitian siklus 1 dan siklus 2 untuk kegiatan pembelajaran diperoleh data capaian kinerja guru dalam melaksanakan pembelajaran sebagai berikut:

Tabel 5.Capaian Kinerja Guru Siklus I dan Siklus II

\begin{tabular}{|c|c|c|}
\hline Aspek PTK & Siklus I & Siklus I \\
\hline Capaian Kinerja Guru & 76,67 & 92,50 \\
& (Baik) & (Amat Baik) \\
\hline
\end{tabular}


Berdasarkan tabel di atas, capaian kinerja guru dengan menggunakan model pembelajaran kooperatif tipe STAD pada siklus I diperoleh nilai 76,67. Sedangkan pada siklus II diperoleh nilai 92,50. Hal ini menunjukkan ada peningkatan capaian kinerja sebesar 15,83 atau 20,65\%. Capaian kinerja guru pada siklus I dan siklus II dapat disajikan dalam grafik berikut:

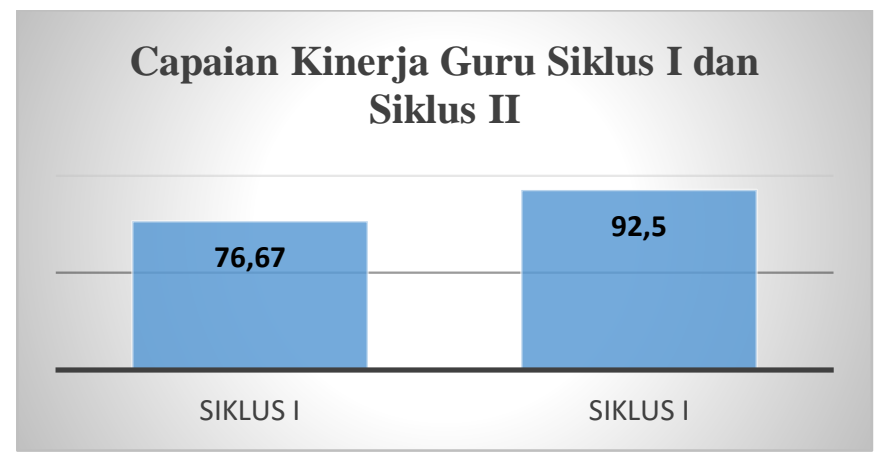

\section{Gambar 1. Grafik Capaian Kenerja Guru Siklus I dan Siklus II}

Berdasarkan grafik di atas disimpulkan bahwa dengan menggunakan model pembelajaran kooperatif tipe STAD dapat meningkatkan capaian kinerja guru dalam melaksanakan proses pembelajaran.

\section{Hasil Belajar Peserta Didik}

a. Hasil Belajar Individu

Berdasar analisis penelitian tindakan kelas siklus I dan siklus II yang sudah diuraikan di atas, untuk hasil belajar peserta didik secara individu diperoleh data sebagai berikut:

Tabel 6. Hasil Belajar Peserta Didik Siklus I dan Siklus II

\begin{tabular}{|c|l|c|c|}
\hline No & Uraian & Siklus I & Siklus II \\
\hline 1 & Rata-Rata & 54.17 & 67,92 \\
\hline 2 & Nilai Tertinggi & 80 & 100 \\
\hline 3 & Nilai Terendah & 20 & 20 \\
\hline
\end{tabular}

Dari tabel di atas terlihat bahwa nilai rata-rata peserta didik dari siklus I dan siklus II mengalami peningkatan. Untuk siklus I nilai rata-ratanya 54,17. Sedangkan pada siklus II nilai rata-ratanya 67,92. Ini menunjukkan ada peningkatan nilai rata-rata 13,75 atau sebesar 20,24\%.

Dari uraian di atas, disimpulkan bahwa dengan menggunakan model pembelajaran kooperatif tipe STAD dapat meningkatkan hasil belajar peserta didik secara individu. Hasil belajar peserta didik pada siklus I dan siklus II dapat disajikan dalam grafik berikut :

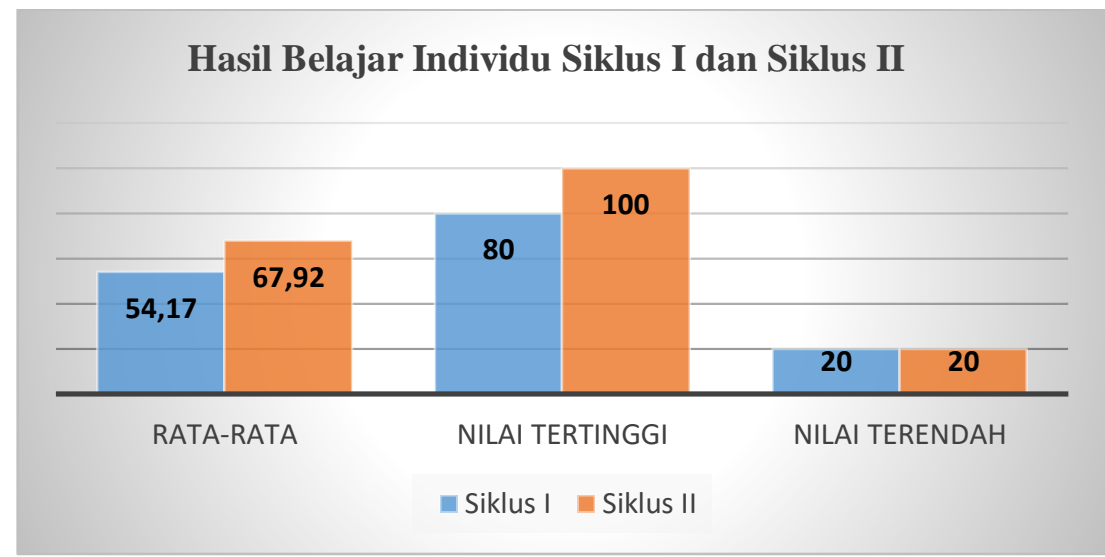

Gambar 2. Grafik Hasil Belajar Individu Siklus I dan Siklus II 
b. Hasil Belajar Kelompok

Berdasar analisis penelitian tindakan kelas siklus I dan siklus II, untuk hasil belajar peserta didik secara individu diperoleh data sebagai berikut:

Tabel 7. Hasil Belajar Kelompok Siklus I dan Siklus II

\begin{tabular}{|c|l|c|c|}
\hline No & Uraian & Siklus I & Siklus II \\
\hline 1 & Rata-Rata & 79 & 87.67 \\
\hline 2 & Nilai Tertinggi & 88 & 92.5 \\
\hline 3 & Nilai Terendah & 61 & 82.5 \\
\hline
\end{tabular}

Dari tabel di atas terlihat bahwa nilai rata-rata hasil belajar kelompok dari siklus I dan siklus II mengalami peningkatan. Untuk siklus I nilai rata-ratanya 72,5, sedangkan pada siklus II nilai rata-ratanya 87,67 . Ini menunjukkan ada peningkatan nilai rata-rata 8,67 atau sebesar $9,89 \%$.

Rata-rata nilai tertinggi hasil belajar kelompok dari siklus I dan siklus II juga mengalami peningkatan. Untuk siklus I rata-rata nilai tertingginya 88, sedangkan pada siklus II rata-rata nilai tertingginya 92,5 . Ini menunjukkan ada peningkatan nilai tertinggi sebesar 4,5 atau 5,11 $\%$.

Rata-rata nilai terendah hasil belajar kelompok dari siklus I dan siklus II juga mengalami peningkatan. Untuk siklus rata-rata nilai terendahnya 61, sedangkan pada siklus II rata-rata nilai terendahnya 82,50. Ini menunjukkan ada peningkatan nilai terendah sebesar 21,5 atau $35,25 \%$.

Hasil belajar peserta didik secara kelompok pada siklus I dan siklus II dapat disajikan dalam grafik berikut :

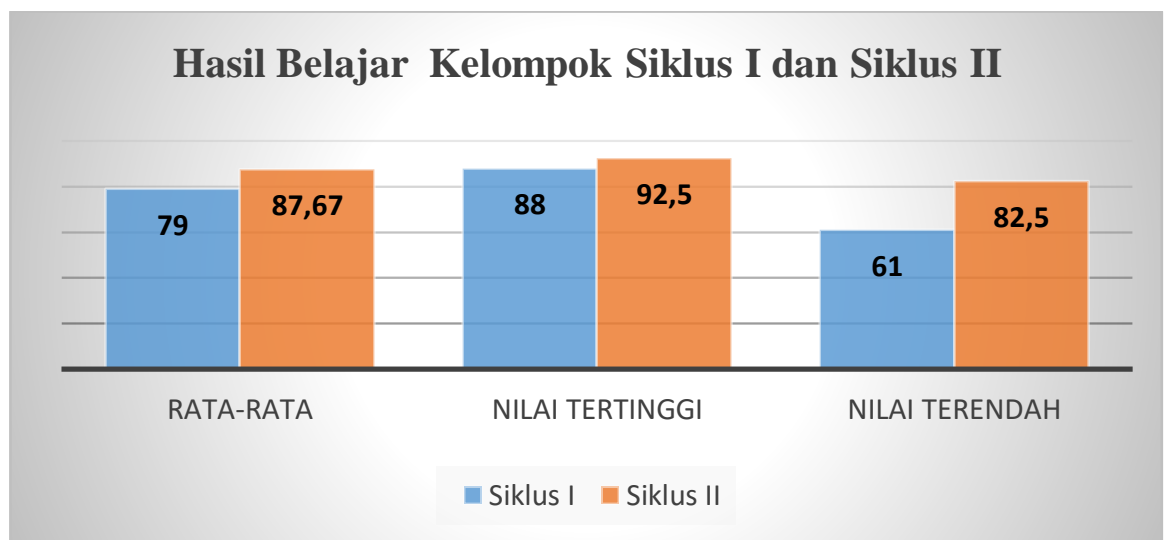

Gambar 3. Grafik Hasil Belajar Kelompok Siklus I dan Siklus II

c. Ketuntasan Hasil Belajar

Berdasar analisis penelitian tindakan kelas siklus I dan siklus II, untuk ketuntasan hasil belajar peserta didik secara diperoleh data sebagai berikut:

Tabel 8. Ketuntasan Hasil Belajar Siklus I Dan Siklus II

\begin{tabular}{|c|c|c|}
\hline Aspek PTK & Siklus I & Siklus II \\
\hline $\begin{array}{c}\text { Ketuntasan Hasil } \\
\text { Belajar }\end{array}$ & $37,50 \%$ & $79,20 \%$ \\
(9 dari 24 peserta didik) & (19 dari 24 peserta didik) \\
\hline
\end{tabular}

Berdasarkan tabel di atas, ketuntasan hasil belajar dengan menggunakan model pembelajaran kooperatif tipe STAD, pada siklus I persentase peserta didik yang telah mencapai nilai ketuntasan sebesar 37,50\% dan pada siklus II sebesar 79,20\%. Ini menunjukkan ada peningkatan persentase ketuntasan hasil belajar peserta didik sebesar 41,70\%. Ketuntasan hasil belajar peserta didik pada siklus I dan siklus II dapat disajikan dalam grafik berikut: 
Ketuntasan Hasil Belajar Siklus I dan Siklus II

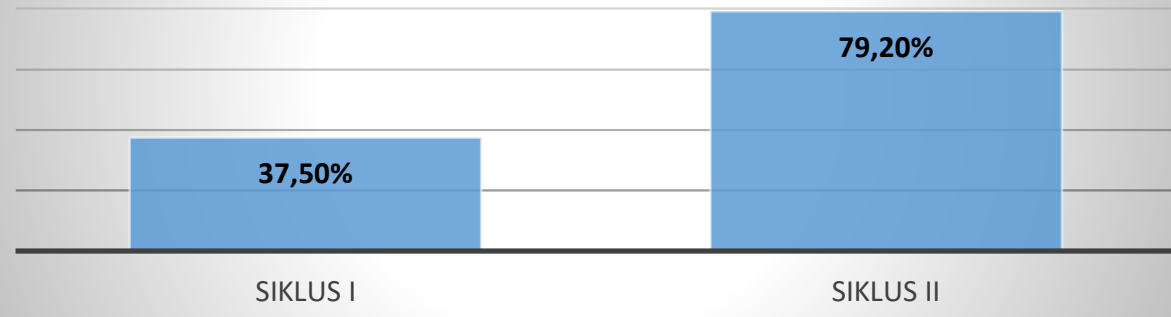

Gambar 4. Grafik Ketuntasan Hasil Belajar Siklus I Dan Siklus II

Dari grafik di atas terlihat bahwa dengan menggunakan model pembelajaran kooperatif tipe STAD dapat meningkatkan persentase ketuntasan hasil belajar peserta didik.

\section{Pencapaian Indikator Keberhasilan}

Berdasar analisis penelitian tindakan kelas siklus I dan siklus II tentang proses pembelajaran dan hasil belajar peserta didik diperoleh tabel sebagai berikut:

Tabel 9. Pencapaian Indikator Keberhasilan Hasil Belajar

\begin{tabular}{|l|l|l|c|c|c|}
\hline No & Aspek PTK & \multicolumn{1}{|c|}{ Indikator Keberhasilan } & Siklus I & Siklus I & Keterangan \\
\hline 1 & $\begin{array}{l}\text { Proses } \\
\text { Pembelajaran }\end{array}$ & $\begin{array}{l}\text { Ada peningkatan capaian } \\
\text { kualitas kinerja dari siklus I } \\
\text { ke siklus II }\end{array}$ & $\begin{array}{c}76,67 \\
\text { (Cukup) }\end{array}$ & $\begin{array}{c}92,50 \\
\text { (Amat } \\
\text { Baik) }\end{array}$ & Tercapai \\
\hline 2 & Hasil Belajar & $\begin{array}{l}\text { Ada peningkatan nilai rata- } \\
\text { rata dari siklus I ke siklus II }\end{array}$ & 54.17 & 67,92 & Tercapai \\
\cline { 2 - 6 } & $\begin{array}{l}\text { Banyaknya peserta didik } \\
\text { yang telah mencapai nilai } \\
\text { KKM minimal 75 \% }\end{array}$ & $\begin{array}{c}37,50 \% \\
(9 \text { dari } 24 \\
\text { peserta } \\
\text { didik) }\end{array}$ & $\begin{array}{c}79,20 \% \\
(19 \text { dari } 24 \\
\text { peserta } \\
\text { didik) }\end{array}$ & Tercapai \\
\hline
\end{tabular}

Dari tabel di atas, untuk proses pembelajaran pada siklus I diperoleh capaian kinerja guru sebesar 76,67 dengan kualifikasi Baik. Sedangkan pada siklus II sebesar 92,50 dengan kualifikasi Amat Baik. Standar indikator keberhasilan PTK untuk aspek proses pembelajaran adalah adanya peningkatan capaian kualitas kinerja guru dari siklus I ke siklus II. Dengan melihat hasil tersebut kegiatan Penelitian Tindakan Kelas ini telah mencapai indikator keberhasilan.

Nilai rata-rata peserta didik dari siklus I dan siklus II mengalami peningkatan. Untuk siklus I nilai rata-ratanya 54,17 dan pada siklus II nilai rata-ratanya 67,92. Hasil belajar peserta didik pada kegiatan pembelajaran siklus I diperoleh data peserta didik yang sudah tuntas sebanyak 9 peserta didik dari 24 peserta didik atau 37,50\%. Sedangkan pada siklus II diperoleh data peserta didik yang sudah mencapai ketuntasan sebanyak 19 dari 24 peserta didik atau 79,20\%. Dengan standar indikator keberhasilan PTK adalah terjadi peningkatan nilai rata-rata hasil belajar dan banyaknya peserta didik yang tuntas mencapai minimal 75\%. Melihat hasil tersebut kegiatan PTK ini sudah mencapai indikator keberhasilan.

Berdasarkan kajian teori yang penulis jadikan dasar pemikiran dalam penelitian ini, maka terdapat relevansi dengan hasil penelitian lapangan. Teori-teori yang dikemukakan para ahli pendidikan terbukti dalam penelitian ini. Menurut Lundgren (dalam Rusman, 2010) tujuan penting dalam pembelajaran kooperatif adalah untuk mengajarkan kepada peserta didik ketrampilan kerja sama dan kolaborasi. Keterampilan ini amat penting untuk dimiliki didalam masyarakat. Dalam pembelajaran kooperatif tidak hanya mempelajari materi saja. Namun, peserta didik juga harus mempelajari keterampilan-keterampilan khusus yang disebut 
keterampilan kooperatif. Keterampilan kooperatif ini berfungsi untuk melancarkan hubungan, kerja dan tugas. Peranan hubungan kerja dapat dibangun dengan mengembangkan komunikasi antar anggota kelompok, sedang peranan tugas dilakukan dengan membagi tugas antar anggota kelompok selama kegiatan.

Berdasarkan teori tersebut penulis berpendapat bahwa terbukti dengan cara belajar berkelompok dan saling membantu antara peserta didik yang satu dengan peserta didik yang lainnya dalam belajar ternyata hasilnya sangat memuaskan. Karena dengan saling bantu dalam mengkaji, mendalami atau memahami materi pembelajaran, maka hal ini akan sangat berpengaruh secara positif terhadap peningkatan hasil belajar peserta didik, karena mereka akan saling mengejar ketertinggalannya dalam penguasaan materi pembelajaran tersebut dengan bantuan pengajar maupun teman sebayanya. Hal ini dapat dilihat pada hasil observasi pengamatan proses pembelajaran oleh observer.

Teori lain yang penulis jadikan dasar berfikir dalam penelitian ini adalah pendapat dari Slavin (2010) yang menyatakan bahwa pembelajaran kooperatif merupakan strategi belajar mengajar yang menekankan pada perilaku atau sikap bekerja sama atau membantu sesame dalam struktur kerja sama yang teratur dalam kelompok dan terdiri dari dua orang atau lebih. Teori inilah yang penulis jadikan dasar pemikiran dalam model pembelajaran kooperatif tipe STAD, di mana peserta didik diberikan tugas kelompok, mengerjakan kuis, mempresentasikan hasil kerja kelompok. Diharapkan kegiatan tersebut akan dapat menimbulkan suasana pembelajaran yang lebih menarik dan tidak membosankan bagi peserta didik. Hal ini terbukti sangat positif bagi upaya penciptaan kondisi pembelajaran yang kondusif.

Dengan berdasarkan data-data hasil temuan selama pelaksanaan proses pembelajaran dengan mengimplementasikan pembelajaran kooperatif tipe STAD, maka penulis menyimpulkan bahwa dari teori yang penulis jadikan dasar berfikir dalam penelitian ini adalah sangat relevan dan menunjukkan hasil yang positif dalam peningkatan hasil belajar peserta didik.

Perbandingan hasil penelitian umum sebelumnya dengan hasil penelitian ini adalah sebagaimana tertuang dalam tabel berikut ini:

Tabel 10. Perbandingan Hasil Penelitian Dengan Penelitian Sebelumnya

\begin{tabular}{|c|c|c|c|c|c|c|c|c|c|c|c|c|}
\hline \multirow[t]{3}{*}{ Siklus } & \multicolumn{9}{|c|}{ Penelitian Sebelumnya } & \multirow{2}{*}{\multicolumn{3}{|c|}{ Hasil Penelitian }} \\
\hline & \multicolumn{3}{|c|}{ Kharis Fajar Martin (2011) } & \multicolumn{3}{|c|}{$\begin{array}{c}\text { Muhammad Takdir } \\
(2013)\end{array}$} & \multicolumn{3}{|c|}{ Hendra (2017) } & & & \\
\hline & $\begin{array}{l}\text { Rata- } \\
\text { rata }\end{array}$ & $\begin{array}{l}\text { Tuntas } \\
(\%)\end{array}$ & $\begin{array}{c}\text { Belum } \\
\text { Tuntas } \\
(\%)\end{array}$ & $\begin{array}{l}\text { Rata- } \\
\text { rata }\end{array}$ & $\begin{array}{l}\text { Tuntas } \\
(\%)\end{array}$ & $\begin{array}{c}\text { Belum } \\
\text { Tuntas } \\
(\%)\end{array}$ & $\begin{array}{l}\text { Rata- } \\
\text { rata }\end{array}$ & $\begin{array}{c}\text { Tuntas } \\
(\%)\end{array}$ & $\begin{array}{c}\text { Belum } \\
\text { Tuntas } \\
(\%)\end{array}$ & $\begin{array}{l}\text { Rata- } \\
\text { rata }\end{array}$ & $\begin{array}{l}\text { Tuntas } \\
(\%)\end{array}$ & $\begin{array}{c}\text { Belum } \\
\text { Tuntas } \\
(\%)\end{array}$ \\
\hline I & 59,67 & 56,67 & 43,33 & 63,4 & - & - & 67,55 & 46 & 54 & 54.17 & 37,50 & 62,50 \\
\hline II & 66,03 & 68,96 & 31,04 & 78,7 & - & - & 73.98 & 69 & 31 & 67,92 & 79,20 & 20,80 \\
\hline III & 73,35 & 83,33 & 16,67 & - & - & - & - & - & - & - & - & - \\
\hline
\end{tabular}

Penemuan hasil penelitian umum yang relevan yang dilakukan oleh Kharis Fajar Martin tahun 2011, mahasiswa FKIP Universitas Lampung dengan judul "Upaya Meningkatkan Aktivitas dan Hasil Belajar Matematika melalui Pembelajaran Kooperatif Tipe STAD (Studi Pada Siswa XI IPA SMA Budaya Bandar lampung Tahun Pelajaran 2010/2011)". Rata-rata hasil belajar matematika siswa pada siklus I sebesar 59,67, siklus II sebesar 66,03 dan siklus III sebesar 73,5 dengan persentase siswa yang tuntas belajar matematika pada siklus I sebesar $56,67 \%$, siklus II sebesar 68,96\% dan siklus III sebesar 83,33\%

Penelitian yang dilakukan oleh Muhammad Takdir tahun 2013, Guru SMA Negeri 1 Pitumpanu pada tahun pelajaran 2013/2014, dengan judul "Peningkatan Hasil Belajar Matematika melalui Pembelajaran Kooperatif Tipe STAD pada Siswa Kelas X.F SMA Negeri 1 Pitumpanu." Hasil yang dicapai setelah pembelajaran kooperatif tipe STAD yaitu hasil 
penelitian untuk Siklus I diperoleh skor rata-rata hasil belajar siswa sebesar 63,4. Untuk Siklus II diperoleh skor rata-rata hasil belajar siswa sebesar 78,7.

Penelitian yang dilakukan oleh Hendra tahun 2017, Guru SMA N 1 Bangkinang, dengan judul "Peningkatan Hasil Belajar Matematika Siswa Kelas XI IPA SMA Negeri 1 Bangkinang Melalui Model Pembelajaran Kooperatif Tipe STAD.. Untuk siklus I nilai rata-ratanya 54,17 dan pada siklis II nilai rata-ratanya 67,92. Ini menunjukkan ada peningkatan nilai rata-rata 13,75 atau sebesar 20,24\%.Hasil belajar peserta didik pada kegiatan pembelajaran siklus I diperoleh data peserta didik yang sudah tuntas sebanyak 9 peserta didik dari 24 peserta didik atau 37,50\%. Sedangkan pada siklus II diperoleh data peserta didik yang sudah mencapai ketuntasan sebanyak 19 dari 24 peserta didik atau 79,20\%.

Tabel di atas menunjukkan perbandingan perolehan hasil belajar antara penelitian umum sebelumnya dengan penelitian ini. Hasilnya adalah menunjukkan bahwa dengan menggunakan model pembelajaran kooperatif tipe STAD materi vektor menunjukkan hasil yang baik. Berdasarkan landasan teori penelitian ini dan berdasarkan pengalaman penulis dalam melaksanakan proses pembelajaran dengan inovasi ini, maka penulis berpendapat bahwa inovasi solusi permasalahan dalam proses pembelajaran dengan model pembelajaran kooperatif tipe STAD ini bisa digunakan dalam mengkaji materi matematika yang lain, bahkan bisa digunakan untuk mata pelajaran yang lain.

\section{KESIMPULAN}

Berdasarkan analisis data di atas, disimpulkan bahwa penerapan model pembelajaran kooperatif tipe STAD dapat meningkatkan hasil belajar peserta didik secara individu. Nilai ratarata peserta didik dari siklus I dan siklus II mengalami peningkatan. Untuk siklus I nilai rataratanya 54,17. Sedangkan pada siklus II nilai rata-ratanya 67,92. Ini menunjukkan ada peningkatan nilai rata-rata 13,75 atau sebesar $20,24 \%$. Persentase ketuntasan hasil belajar peserta didik pada siklus I sebesar 37,50\% dan pada siklus II sebesar 79,20\%.

Penggunaan model pembelajaran tipe STAD dapat digunakan sebagai alternatif dalam melakukan kegiatan pembelajaran di kelas dengan melakukan inovasi dan kreatifitas pembelajaran yang ingin dicapai. Kepada guru-guru matematika hendaknya secara sadar mengubah kebiasaan mengajar dari yang bersifat pemberi informasi mutlak (mendominasi pembelajaran) ke metode inteaksi aktif peserta didik dengan fasilitator dan peserta didik dengan sesama peserta didik.

\section{DAFTAR PUSTAKA}

Arikunto, Suharsimi, dkk. (2010). Penelitian Tindakan Kelas. Jakarta: Bumi Aksara

Hendra. (2018). Peningkatan Hasil Belajar Matematika Siswa Kelas XI IPA SMA Negeri 1 Bangkinang Melalui Model Pembelajaran Kooperatif Tipe STAD. Jurnal Cendekia: Jurnal Pendidikan Matematika, Volume 2, No. 2, Agustus 2018, hal. 29 - 41.

Martin, Kharis Fajar. (2011). Upaya Meningkatkan Aktivitas dan Hasil Belajar Matematika melalui Pembelajaran Kooperatif Tipe STAD (Studi Pada Siswa XI IPA SMA Budaya Bandar lampung Tahun Pelajaran 2010/2011). Skripsi. FKIP Universitas Lampung. Lampung

Pemerintah Indonesia. (2009). Permeneg PAN dan RB No 16 tahun 2009 tentang Jabatan Fungsional Guru dan Angka Kreditnya. Jakarta : Depdiknas.

Rusman. (2010). Model-model Pembelajaran: Mengembangkan Profesionalisme Guru. Jakarta : Rajawali Press.

Slavin, Robert E. (2010). Cooperative Learning: Teori, Riset dan Praktik. Bandung: Nusa Media.

Takdir, Muhammad. (2014). Peningkatan Hasil Belajar Matematika melalui Pembelajaran Kooperatif Tipe STAD pada Siswa Kelas X.F SMA Negeri 1 Pitumpanu. Jurnal Nalar Pendidikan Volume 2, Nomor 1, 